\section{GC-MS Identification of Dimethyl Sulfone in Cow's Milk and Other Livestock Products}

\author{
Masaaki IMANAKA, \\ Kazuyoshi Matsunaga and \\ Tatsuo IsHIDA \\ Okayama Prefectural Research Center of \\ Environment and Public Health, \\ Uchio, Okayama 701-02, Japan
}

(Received November 8, 1984)

\section{INTRODUCTION}

Recently, the general practice of raising farm animals on a large scale in order to supply livestock products at reasonable prices has resulted in an expansion of the quantity of drugs used for animals. ${ }^{1)}$ Especially, organophosphorus insecticides have been used extensively for controlling harmful insects such as mosquitos and flies. After spraying, these drugs may come in direct contact with animals and persist in the livestock products. To keep abreast of the problem, surveys conducted from July-Sept. 1980-1982, indicated that there were no insecticide residues in the livestock foodstuffs produced in Okayama Prefecture.

During the investigation of Trichlorfon (DEP) residues, an unidentified peak with a retention time shorter than that for DEP and Dichlorvos (DDVP) was detected on FPD gaschromatograms (P-mode) predominantly in cow's milk and in chicken meat and liver, etc.

This paper reports the identification of this compound in cow's milk.

\section{MATERIALS AND METHODS}

\section{Reagents}

All solvents and anhydrous sodium sulfate $\left(\mathrm{Na}_{2} \mathrm{SO}_{4}\right)$ were of pesticide analysis grade. Dimethyl sulfone $\left(\mathrm{DMSO}_{2}\right)$, benzothiophene, dibenzothiophene and dibutyl sulfide were G.R. grade. DDVP, DEP and ethylthiometone were purchased from Wako Pure Chemical Industries, Ltd. (Osaka, Japan). GC-column packings were supplied by Shinwa-kako Co., Ltd. Packing Center (Kyoto, Japan).

\section{Apparatus and Operating Conditions}

Gaschromatograph, Shimadzu 4BM-PF equipped with a FPD (P or S filter); Operating parameters are listed in Table 1.

GC-MS; Shimadzu LKB-9000; column, $1.0 \mathrm{~m} \times$ $3 \mathrm{~mm} \phi$, glass; stationary phase, $5 \%$ Thermon 3000; support, Chromosorb W (AW-DMCS), 80/ $100 \mathrm{mesh}$; carrier gas, He $(25 \mathrm{ml} / \mathrm{min})$; column temp., $120-160^{\circ} \mathrm{C}, 4^{\circ} \mathrm{C} / \mathrm{min}$; inj. and separation temp., $220^{\circ} \mathrm{C}$; ion source temp., $290^{\circ} \mathrm{C}$; electron energy, $70 \mathrm{eV}$; accelerating voltage, $3.5 \mathrm{kV}$; trap current, $60 \mu \mathrm{A}$.

\section{Preparation of Sample Solution \\ 3.1 Analytical method for DEP in livestock products \\ The method reported by Takase et al. ${ }^{2)}$ was} applied with modifications. ${ }^{3)}$ About $1 \mathrm{~kg}$ of chicken meat or liver was ground and mixed well. A $50 \mathrm{~g}$ portion of the sample was extracted three times by shaking vigorously with $\mathrm{CH}_{3} \mathrm{CN}$ (100 $\mathrm{ml} \times 1$ and $50 \mathrm{ml} \times 2$ ) for $10 \mathrm{~min}$. The extracts were all combined and $50 \mathrm{ml}$ of phosphate buffer solution ( $\mathrm{pH}$ 5.8) containing $5 \% \quad \mathrm{NaCl}$ was added. In case of cow's milk, $25 \mathrm{ml}$ of the sample was placed in a centrifuge tube and extracted with three $50 \mathrm{ml}$ aliquots of $\mathrm{CH}_{3} \mathrm{CN}$ by shaking well. The supernatants obtained by centrifugation were combined.

The $\mathrm{CH}_{3} \mathrm{CN}$ layer containing water was extracted three times with $\mathrm{CHCl}_{3}(100 \mathrm{ml} \times 1$ and $50 \mathrm{ml} \times 2$ ) and the $\mathrm{CHCl}_{3}$ layer was evaporated under reduced pressure below $40^{\circ} \mathrm{C}$ after dried over anhydrous $\mathrm{Na}_{2} \mathrm{SO}_{4}$.

The obtained fat was dissolved in $20 \mathrm{ml}$ of $n$ hexane and re-extracted with two $30 \mathrm{ml}$ aliquots of $\mathrm{CH}_{3} \mathrm{CN}$ saturated with $n$-hexane. The extracts were combined and concentrated to less than 10 $\mathrm{ml}$ below $40^{\circ} \mathrm{C}$ under reduced pressure, to which was added $50 \mathrm{ml}$ of phosphate buffer solution containing $2 \% \mathrm{NaCl}$. The aqueous layer was washed with three $50 \mathrm{ml}$ aliquots of $n$-hexane and extracted with four $50 \mathrm{ml}$ of $\mathrm{CH}_{2} \mathrm{Cl}_{2}$. The combined extract was dried over anhydrous $\mathrm{Na}_{2} \mathrm{SO}_{4}$ and evaporated to dryness below $40^{\circ} \mathrm{C}$ under reduced pressure. The residue was dissolved in 1-5 $\mathrm{ml}$ acetone and $5 \mu \mathrm{l}$ of the sample solution was subjected to a gaschromatograph equipped with a FPD (P-mode). 
Table 1 GC operating conditions. ${ }^{\text {a) }}$

\begin{tabular}{|c|c|c|c|c|c|c|}
\hline \multirow{2}{*}{ No. } & \multirow{2}{*}{$\begin{array}{l}\text { Stationary phase } \\
5 \% \text { Thermon } 3000\end{array}$} & \multicolumn{2}{|l|}{ Support } & \multicolumn{2}{|c|}{$\underset{\left({ }^{\circ} \mathrm{C}\right)}{\text { Column temp. }}$} & \multirow{2}{*}{$\begin{array}{c}\text { Column length } \\
(\mathrm{m}) \\
1.0\end{array}$} \\
\hline & & $W^{b)}$ & $(80 / 100)$ & $120-180$ & $6 / \mathrm{min}$ & \\
\hline B & $3 \%$ Thermon 3000 & Shimalite TPA & $(60 / 80)$ & $120-160$ & $6 / \mathrm{min}$ & $0.3,1.0 \& 2.0$ \\
\hline $\mathrm{C}$ & $25 \%$ PEG-20M & Gaschrom Q & $(80 / 100)$ & 200 & & 2.0 \\
\hline $\mathrm{D}$ & $2 \%$ Dexsil $300 \mathrm{GC}$ & W-HP & $(80 / 100)$ & $120-180$ & $6 / \mathrm{min}$ & 2.0 \\
\hline $\mathrm{E}$ & $10 \%$ OV -1 & $\mathrm{~W}$ & $(80 / 100)$ & 90 & & 1.0 \\
\hline
\end{tabular}

a) Detector; FPD (P or S filter): Detector Temp. $300^{\circ} \mathrm{C}$ : Injection Temp. $250^{\circ} \mathrm{C}$. Flow rate; $\mathrm{N}_{2}=60 \mathrm{ml} / \mathrm{min}, \mathrm{H}_{2}=\mathrm{Air}=40 \mathrm{ml} / \mathrm{min}$.

b) W; Chromosorb W (AW-DMCS).

\subsection{Extraction method for the unidentified com- pound in cow's milk}

In a $100 \mathrm{ml}$ centrifuge tube, $25 \mathrm{ml}$ aliquot of cow's milk was placed and extracted with $50 \mathrm{ml}$ of $\mathrm{CH}_{3} \mathrm{CN}$ by shaking for about $5 \mathrm{~min}$. The mixture was centrifuged at $3000 \mathrm{rpm}$ for about 5 min. The residue was similarly re-extracted with two $50 \mathrm{ml}$ aliquots of $\mathrm{CH}_{3} \mathrm{CN}$. After adding 50 $\mathrm{ml}$ of $5 \% \mathrm{NaCl}$ solution to the combined $\mathrm{CH}_{3} \mathrm{CN}$ layer, the mixture was extracted three times with $\mathrm{CHCl}_{3}(100 \mathrm{ml} \times 1$ and $50 \mathrm{ml} \times 2)$. The combined $\mathrm{CHCl}_{3}$ layer was dried over anhydrous $\mathrm{Na}_{2} \mathrm{SO}_{4}$ and concentrated to $10 \mathrm{ml}$ below $40^{\circ} \mathrm{C}$ under reduced pressure. The concentrate was dissolved in acetone to make $20 \mathrm{ml}$. One $\mu \mathrm{l}$ was injected into FPD.GC with $\mathrm{P}$ - or S-mode.

\section{RESULTS AND DISCUSSION}

\section{Unknown Compound in DEP Test Solutions of Livestock Products}

No residual DEP was found (detection limit, $0.002 \mu \mathrm{g} / \mathrm{g}$ ) in the livestock foodstuffs tested, but most of the analyses demonstrated an unidentified peak on the FPD gaschromatograms using a P-filter (Fig. 1). The concentration of unknown compound in cow's milk was considerably higher when compared with that of meat and liver.

The peak height of the unknown compound varied widely even among the five samples which were taken from the same specimens of cow's milk. Here, each extract was concentrated carefully to dryness or to $2-3 \mathrm{ml}$ below $40^{\circ} \mathrm{C}$ under reduced pressure, and the residues were diluted with acetone to a fixed volume before the injection into FPD $\cdot G C$. The relative retention time of the unknown compound to DDVP was 0.69 , and the result suggests that concentration under reduced pressure might primarily cause loss of the compound because of its high volatility.

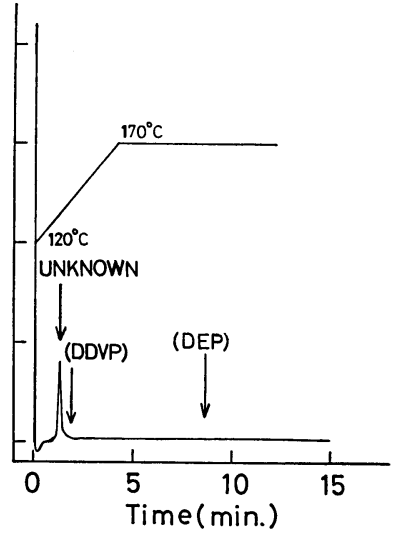

Fig. 1 FPD (P-mode) gaschromatogram of the extract from the chicken liver.

The sample solution (sample: $50 \mathrm{~g}$ ) was prepared according to the analytical method (MATERIALS AND METHODS 3.1). GC conditions; $3 \%$ Thermon 3000 on Shimalite TPA: $60 / 80$ mesh, column length: $\phi 3 \mathrm{~mm}-0.3 \mathrm{~m}$, column temp.: $120-170^{\circ} \mathrm{C}, 12^{\circ} \mathrm{C} / \mathrm{min}, \mathrm{N}_{2}: 60 \mathrm{ml} /$ $\min$, Air: $60 \mathrm{ml} / \mathrm{min}, \mathrm{H}_{2}: 120 \mathrm{ml} / \mathrm{min}$.

2. Peak Height Ratio of the Unknown Compound with S-mode to P-mode on FPD Gaschromatograms

Being intensely luminous when a P-filter was attached to FPD, the unknown compound in cow's milk represented by an unidentified peak was presumed to be an organophosphorus compound. However, the peak-height with S-mode was markedly higher than that with P-mode, suggesting that the unknown compound might be either an organophosphorus compound containing $\mathrm{S}$ atom in its molecule, or an organosulfur compound. Ratios of peak-height recorded in $\mathrm{S}$-mode to $\mathrm{P}$-mode are listed in Table 2 in various organosulfur compounds, an organophosphorus 
Table 2 The peak height ratios with $\mathrm{S}$ - to $\mathrm{P}$ mode of seven compounds on FPD gaschromatograms.

\begin{tabular}{ll}
\hline \multicolumn{1}{c}{ Compounds } & S/P Ratios \\
\hline Unknown $^{\mathrm{a})}$ & 44.5 \\
$\mathrm{DMSO}_{2}$ & 43.6 \\
Monobenzothiophene $_{\text {Dibenzothiophene }}$ & 47.5 \\
Dibuthyldisulfide & 41.9 \\
Ethylthiometone & 41.3 \\
DDVP & 1.22 \\
\end{tabular}

a Unknown: the unknown compound in cow's milk.

pesticide containing $\mathrm{S}$ atom in its molecule and DDVP. The ratio of the unknown compound agrees with those of organosulfur compounds, suggesting that the unknown compound is an organosulfur compound.

\section{Polarity Examination of the Unknown Com- pound}

The unknown compound consistently showed a distinct and reproducible peak only when chromatographed under conditions A-C, highly polar stationary phases, given in Table 1 . On the other hand, only very badly smeared peaks were obtained when chromatographed under the conditions of $\mathrm{D}$ and $\mathrm{E}$ with poor to moderate polar stationary phases. When injection into FPD.GC was repeated under condition $D$, the retention time of the unknown compound gradually decreased from $9.3 \mathrm{~min}$ in the first run to 5.8 min in the 7 th run. These facts suggest that the unknown compound has high polarity.

In order to estimate the polarity, a fixed amount of the unknown compound (which has been extracted and purified according to the method 3.1) was dissolved in a $5 \% \mathrm{NaC}$ aqueous solution at various volumes from 50 to $500 \mathrm{ml}$, then the recovery rate was investigated after it was extracted with $100 \mathrm{ml}$ of $\mathrm{CHCl}_{3}$. The recovery rates expressed in terms of peak-height markedly decreased with an increase in volume of $\mathrm{NaCl}$ solution (Fig. 2). This indicates that the unknown compound is highly polar.

\section{Identification}

Because of its high water solubility, about $10 \%$ of the compound remained in an aqueous solution even after the third extraction with $\mathrm{CHCl}_{3}$ in the method 3.2. As substances such as fats which might have interfered with FPD gaschromatog-

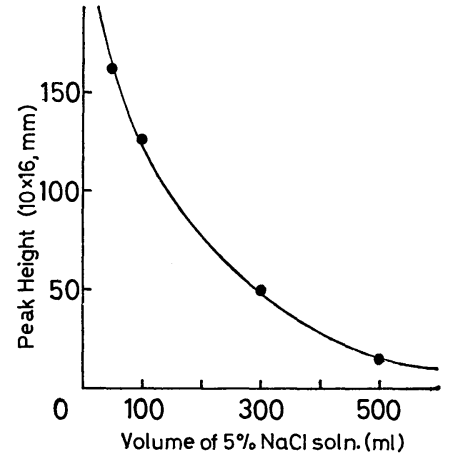

Fig. 2 The effect of the amount of $5 \% \mathrm{NaCl}$ solution on the extraction efficiency of the unknown compound with $\mathrm{CHCl}_{3}$.

One hundred $\mathrm{ml}$ of $\mathrm{CHCl}_{3}$ was used.

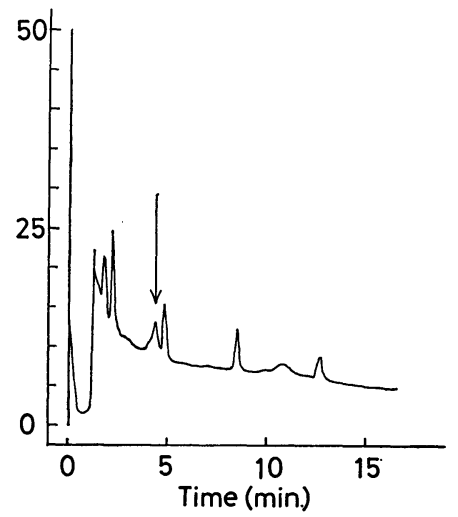

Fig. 3 Total ion chromatogram of the extract from cow's milk.

GC-MS conditions are listed in the experimental section (MATERIALS AND METHODS 2.). Electron energy in GC-MS was $20 \mathrm{eV}$.

raphy had been mostly removed by the three previous extractions with $\mathrm{CHCl}_{3}$, the sample solutions appropriate for GC-MS were prepared by further extraction of the aqueous layer with two $50 \mathrm{ml}$ of $\mathrm{CHCl}_{3}$. The total ion chromatogram (TIC) of the extract thus prepared from cow's milk is given in Fig. 3, and the Electron Impact (EI) mass spectrum of the unknown compound is shown in Fig. 4 B. On the EI mass spectrum, an ion about $4 \%$ as strong as that locating at $\mathrm{m} / \mathrm{z}$ 94 was demonstrated at $m / z 96(m / z: \mathbf{M}+2)$, indicating that this compound is of molecular weight 94 and contains one sulfur atom per one molecule. Furthermore from the EI mass spectrum of Fig. $4 \mathrm{~A}$, the compound was identified to be $\mathrm{DMSO}_{2}$. 


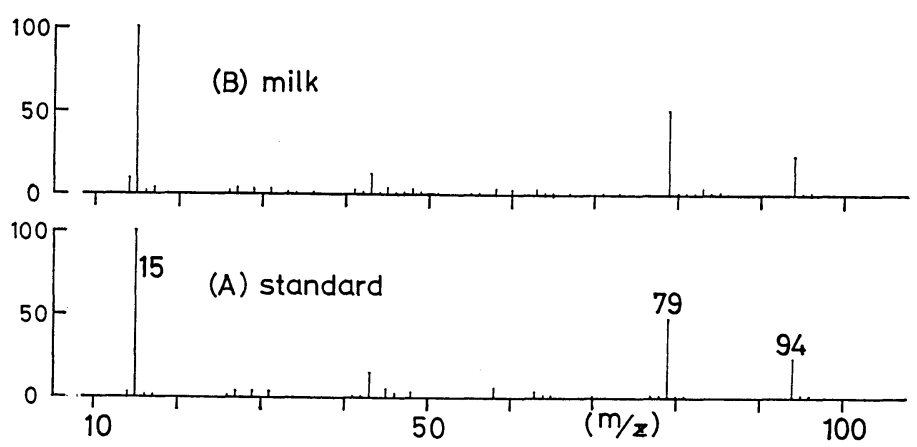

Fig. 4 Electron impact (EI) mass spectra of dimethyl sulfone standard and the unknown compound.

(A) Dimethyl sulfone standard, (B) Unknown compound from cow's milk. GC-MS conditions are listed in the experimental section (MATERIALS AND METHODS 2.).

The presence of $\mathrm{DMSO}_{2}$ in human urine ${ }^{4)}$ and cow's milk ${ }^{5}$ has been previously reported by Williams et al. who detected it in the course of the study on metabolism of dimethylsulfide (DMS) in vivo. The FPD, however, had not developed yet in those days ${ }^{6)}$ and no gaschromatogram of $\mathrm{DMSO}_{2}$ was recorded. Since then, few papers ${ }^{7,8)}$ have been published regarding $\mathrm{DMSO}_{2}$ in livestock products, possibly due to the difficulties inherent in its chemical properties. Because of its high water solubility, the amount of $\mathrm{DMSO}_{2}$ extracted with organic solvents is low and once extracted, it becomes volatile and is apt to evaporate during concentration.

The authors have, so far, analyzed about 100 liverstock products in the survey of residual organophosphorus pesticides (Diazinon, DDVP, Dimethoate, Fenitrothion, Malathion etc. except $\mathrm{DEP}$ ). No $\mathrm{DMSO}_{2}$ peak, however, was noted on FPD gaschromatograms, possibly because a large amount $(500 \mathrm{ml})$ of aqueous solution was used during the clean-up process.

Recently, Pearson et al. ${ }^{8)}$ reported that a varity of fruits, vegetables and beverages contained trace of $\mathrm{DMSO}_{2}$ as one of their natural components. However, it is not clear why $\mathrm{DMSO}_{2}$ exists naturally in these products.

Apart from this, $\mathrm{DMSO}_{2}$ itself is industrially synthesized ${ }^{9)}$ and dimethyl sulfoxide (DMSO), which is converted into $\mathrm{DMSO}_{2}$ in the environment ${ }^{10)}$ and in rabbits, ${ }^{11)}$ is also mass produced and utilized as an industrial solvent. This situation seems to be reflected in that both compounds rank high in the Priority List ${ }^{12}$ published by the Environmental Agency of Japan. Coleman et al. ${ }^{13)}$ in the U.S. Environmental Protection Agency reported the presence of $\mathrm{DMSO}_{2}$ in drinking water. $\mathrm{DMSO}_{2}$ was also found to inhibit the growth of some microorganisms. ${ }^{14)}$ Furthur studies to monitor $\mathrm{DMSO}_{2}$ distribution in the environment are necessary.

\section{REFERENCES}

1) T. Hayama: J. Pesticide Sci. 5, 627 (1980) (in Japanese)

2) I. Takase, T. Nakahara, Y. Yoshimoto \& H. Nakamura: Botyukagaku 37, 142 (1972) (in Japanese)

3) M. Imanaka, K. Matsunaga \& T. Ishida: $J$. Food Hyg. Soc. Jpn. 22, 472 (1981) (in Japanese)

4) K. I. H. Williams, S. H. Burstein \& D. S. Layne: Arch. Biochem. Biophys. 113, 251 (1966)

5) K. I. H. Williams, S. H. Burstein \& D. S. Layne: Proc. Soc. Exp. Biol. Med. 122, 865 (1966)

6) T. Kojima, M. Itaya \& T. Sugiyama: "Recent Developments in Gas Chromatography," ed. by T. Takeuchi \& S. Tsuge, Nankodo, Tokyo, p. 73, 1978 (in Japanese)

7) D. C. Kulshrestha \& E. H. Marth: J. Milk Food Technol. 38, 604 (1975)

8) T. W. Pearson, H. J. Dawson \& H. B. Lackey: J. Agric. Food Chem. 29, 1089 (1981)

9) M. Windholz, S. Budavari, R. F. Blumetti \& E. S. Otterbein: "The Merck Index," 10th ed., Merck \& Co., Inc., Rahway, p. 475, 1983

10) M. O. Andreae: Anal. Chem. 52, 150 (1980)

11) K. I. H. Williams, K. S. Whittemore, T. N. Mellin \& D. S. Layne: Science 149, 203 (1965)

12) Office of Health Studies, Department of Environmental Health, Environmental Agency: "Chemicals in the Environment," 1978 Environmental Agency, Japan, p. 132, 1978 (in Japanese)

13) W. E. Coleman, R. G. Melton, F. C. Kopfler, K. A. Barone, T. A. Aurand \& M. G. Jellison: 
Environ. Sci. Technol. 14, 576 (1980)

14) W. A. Clark \& R. L. Salsbury: J. Dairy Sci. 63, 375 (1980)

\section{要 約}

ガスクロマトグラフ-翼量分析計法 (GC-MS) による 畜産食品中のジメチルスルホンの同定

今中雅章, 松永和義, 石田立夫 畜産食品(とくに牛乳) 中に残留するトリクロルホン (DEP) 等 の実態調査の際に, DEP やジクロルボスよりも短い保持時間を 有する未知ピークが，Pフィルターを使用する FPD ガスクロマ トグラム上で見いだされた. 音産業における動物用医薬品の使 用量が増大している現状から, 有機リン農薬あるいはその代謝 物が残留していることが㲘念されたため，その同定を主眼とし
て詳細に検討した. FPD・GC を使用し，P/S 両フィルターに 対する応答性, 各種の $\mathrm{GC}$ 充てん剂上でのピーク形状等を調查 した結果, この未知物質は非常に極性の強い有機イオウ化合物 であることが示唆された。 そこで, この水溶性が強い性質を利 用したクリーン・アップ方法を考案し，GC-MS で分析したとと ろ, ジメチルスルホンであると同定された，通常の残留農薬分 析法ではジメチルスルホンのピークが検出されることはないが， 水溶性の強い DEPを対象とする場合には, クリーン・アップ段 階で少量の水溶液しか使用しないために, 強極性の有機リン農 薬と同一画分にかなりな濃度で混入し，P フィルター使用時に も明瞭なピークを形成したものである.なお，ジメチルスルホ ンは正常代謝物の一つであるが，環境污染物質としての観点か らも，今後着目されるべき化合物であると考えられる. 